BOZSIK GABRIELLA

Eszterházy Károly Főiskola, Eger

\title{
JUBILEUMI VISSZATEKINTÉS A NAGY J. BÉLA HELYESÍRÁSI VERSENY TÖRTÉNETÉRE ${ }^{1}$
}

Az anyanyelvi műveltség fontos eleme volt és lesz a tanulók helyesírástudása, amely egyebek mellett eszközként szolgál mindenféle ismeret megszerzéséhez, a gondolkodásfejlesztésben pedig nélkülözhetetlen terület. Az egri föiskola magyar nyelvészeti tanszéke mindezeket a megállapításokat szem előtt tartotta a magyartanárképzésben, ezért az 1960-as évektől kezdődően rendszeresen megszervezte az intézményi szintű helyesírási versenyt nem csak magyar szakosoknak, hiszen a helyesírással való törődés össz-nevelőtestületi feladat. Mivel népszerü és hasznos volt a háziverseny, felmerült az igény a résztvevők körének a kibővítésére. 1987-ben hívta meg első ízben az akkori nevén Ho Si Minh Tanárképző Főiskola a pedagógusjelölteket, azaz a tanárképzéssel foglalkozó tudományegyetemek, a tanító- és a tanárképző főiskolák legjobb helyesíróit egy országos megmérettetésre. Ettől kezdve minden évben 22-25 intézmény egy hallgatóval, a háziverseny győztesével kapcsolódott be az egynapos országos döntőbe.

Az 1993-as év több szempontból is nevezetes. Ekkor javasolta Fábián Pál, a rendezvény lelkes szakmai támogatója, hogy a versenynek adjunk nevet. A névadó kapcsán így emlékezett: „Kedves Barátaim és Kollégáim! Kivételes alkalom a mai: az egri főiskola érdeméből immár hagyományossá lett helyesírási versenyünk felveszi Nagy J. Bélának, századunk kiváló magyar nyelvészének nevét, emléket állítva ily módon az ő minden tiszteletet megérdemlő személyének.

Nagy József Béla 1884. március 16-án született a Heves megyei Gyöngyöshalászon a község tanítójának fiaként. Miután a budapesti egyetemen elvégezte a magyar-francia szakot, előbb Körmöcbányán, majd Székesfehérváron tanított a reáliskolában. Ez idő tájt még elsősorban a pedagógia vonzotta: számos didaktikai és neveléstörténeti tanulmányt írt. 1919-ben átvette és 1939-ig szerkesztette a Magyar Paedagogia című folyóiratot. Néhány év múlva viszont már magyar szakos tanárjelölteknek tartott emlékezetes stílusgyakorlatot és módszertani előadásokat. Ekkor már igényes, világos nyelvezetű, kitűnő tankönyvei is megjelentek. 1932-től az akadémiai nyelvművelő folyóirat, a Magyarosan társszerkesztője lett, majd 1945 és 1949 között az ő közreműködésével készültek a lap utolsó évfolyamai. 1936-ban az Akadémia levelező taggá választotta, majd a háború utáni átszervezéskor sok más kiváló tudóssal együtt - törölték a tagok névsorából. Munkásságából az tűnik ki, hogy a kezdeti módszertani-neveléstörténeti irányultságot egy idő után felváltotta

1 Az írás az Anyanyelv-pedagógia címü folyóirat 2017/2-es számában megjelent ismertetés kismértékben módosított, aktualizált utánközlése. 
a nyelvművelésben és a helyesírásban történő elmélyülés. Az akadémiai Nyelvtudományi Bizottság egyik háromtagú albizottságának tagjaként aktívan részt vett az 1954-es helyesírási szabályzat előkészítésében. Észrevételeit, kritikáját, hasznos szakmai javaslatait mindig figyelembe vették tudóstársai. Amikor az Akadémia eldöntötte, hogy szükség lenne egy "Tüzetes magyar helyesirási szótár kiadására, a szerkesztéssel Nagy J. Bélát bízta meg. A szótár elkészült, de 1944 telén a város ostromakor a budapesti Franklin Nyomdában szinte minden elpusztult. Az egyetlen csonkán megmaradt korrektúralevonat, amelyet még meg tudtak menteni, nagy segítséget jelentett a bizottságnak a szabályzat 10. kiadásának összeállításakor. Ezt követően már szinte csak a helyesírást mint tudományterületet választotta, amellyel behatóan foglalkozott" (Fábián 1995: 9-13).

A verseny történetében 1993-hoz köthető továbbá az a változás is, hogy a kezdetben egynaposnak induló országos döntő - a kívánságoknak eleget téve - kibővült egy olyan szakmai programmal, ahol számos kitűnő előadás, bemutatás, szemléltetés foglalkozott helyesírás-elméleti, helyesírás-történeti kérdésekkel. A tematikai gazdagságot a versenyhez kapcsolódó eddig megjelent 9 tanulmánygyüjtemény (kettő megjelenés alatt) ékesen bizonyítja. Mindenképpen említésre méltó, hogy több kolléga a témaválasztásakor nagyon fontosnak tartotta a helyesírás tanításának módszertani problémakörét határainkon innen és túl a magyar anyanyelvűek körében. Amikor egy-egy rendkívül fontos helyesírási kiadvány napvilágot látott, az természetesen a szakmai program középpontjába került. Ilyen volt Fábián Pál, Földi Ervin és Hőnyi Ede munkája, A földrajzi nevek helyesírása 1998-ban, majd a Magyar helyesirási szótár 1999-ben. 2015 őszén, a 25. jubileumi versenyen és konferencián pedig a szakmai program témája természetesen az új, a 12. kiadású akadémiai helyesírási szabályzat volt. Több olyan neves szakember tartott előadást, aki hosszú évekig tevékenyen részt vett a 300 szabálypont és a szótári rész kidolgozásában, összeállításában.

Az előadásokat követő ankéton lehetőséget teremtettek a szervezők arra, hogy főként az elhangzottakhoz kapcsolódóan kérdéseket tegyenek fel a versenyzők, a felkészítő tanáraik, és válaszolhassanak a bírálóbizottság tagjai, a meghívott előadók és más jelen lévő szakemberek. A kérdések tartalma markánsan jelezte, hogy 1987-től 2015-ig az egyes időszakokban mi jelentett nehézséget a diákoknak, tanároknak, mit tartottak például következetlenségnek, nehezen taníthatónak vagy kevésbé észszerünek, mi hiányzott a szabályzatból, mi újat adott a 12. kiadású szabálygyűjtemény stb. Ezek a jó hangulatban eltöltött órák, kötetlen szakmai beszélgetések rendkívül hasznosnak bizonyultak valamennyi résztvevő számára.

Még mindig az 1993-as évnél maradva meg kell említeni azt is, hogy az az évi szakmai programnak és a versenynek az anyagát - tanszéki elhatározásnak köszönhetően - első alkalommal kötetbe rendeztük. A szerkesztők célja ezzel nemcsak az volt, hogy dokumentálják az egyes versenyeken elhangzott előadások anyagát, közzétegyék a győztesek nevét, hanem az előző évek tollbamondásszövegeit és feladatlapjait is bemutassák, megkönnyítve ezzel a hallgatók felkészülését, felkészítését. Kedves szokás lett az is, hogy 
valamennyi versenyen ajándékként minden részt vevő tanár és hallgató kapott egy kötetet, amely a korábbi évek előadásain kívül közöl tollbamondásokat, feladatlapokat, változatos gyakorlatsorokat, teszteket, gyakorlásra szánt mondatgyüjteményeket, különféle felmérések eredményeinek a szakmai értékelését, megemlékezéseket és jól használható helyesírási bibliográfiát.

Ezekhez a kötetekhez könyvesbolti forgalomban nem lehet hozzájutni, de föiskolai, egyetemi könyvtárakban fellelhetők. Két kötet jelenleg megjelenés alatt áll. ${ }^{2}$ A pedagógusjelöltek Nagy J. Béla országos helyesírási versenyéhez kapcsolódó megjelent kötetek:

Bozsik Gabriella - V. Raisz Rózsa (szerk.) 1996. Helyesírásunk elvi és gyakorlati kérdéseiböl. Tanulmányok, cikkek, feladatok. Eszterházy Károly Tanárképző Főiskola. Eger.

O. Bozsik Gabriella - V. Raisz Rózsa - Zimányi Árpád (szerk.) 1996. Helyesírási kultúránk fejlesztéséért. Tizéves a pedagógusjelöltek Nagy J. Béla országos helyesirási versenye. Eszterházy Károly Tanárképző Főiskola. Eger.

O. Bozsik Gabriella - V. Raisz Rózsa - Zimányi Árpád (szerk.) 1998. Helyesírásunkról, helyesirásunkért. A Nagy J. Béla országos helyesirási versenyek elöadásai, egyéb tanulmányok, feladatsorok. Eszterházy Károly Tanárképző Főiskola. Eger.

Bozsik Gabriella - V. Raisz Rózsa (szerk.) 2000. Helyesirás és tanárképzés. A Nagy J. Béla országos helyesirási versenyek elöadásai, egyéb tanulmányok, feladatsorok. Eszterházy Károly Föiskola. Eger.

Bozsik Gabriella - V. Raisz Rózsa (szerk.) 2001-2002. Helyesirásunk idöszerü kérdései a 21. század kezdetén. Eszterházy Károly Főiskola. Eger.

Bozsik Gabriella - V. Raisz Rózsa (szerk.) 2003-2004. Korjelző változások, megoldandó irásmódok. A Nagy J. Béla országos helyesirási verseny elöadásai és egyéb tanulmányok. Eszterházy Károly Főiskola. Eger.

Bozsik Gabriella - Eőry Vilma - V. Raisz Rózsa (szerk.) 2007. Hagyomány és újitás a helyesirásban. Válogatás a Nagy J. Béla országos helyesirási verseny köteteinek anyagaiból. Líceum Kiadó. Eger.

Bozsik Gabriella (szerk.) 2008. Két évtized a helyesirásért. 2005-2007. A Nagy J. Béla országos helyesirási versenyek elöadásai, feladatai, egyéb tanulmányok. Líceum Kiadó. Eger.

Bozsik Gabriella (szerk.) 2013. Helyesirás-tanitásunk helyzete határon innen és túl. A Nagy J. Béla országos helyesirási verseny elóadásai, feladatai és egyéb tanulmányok. Eszterházy Károly Főiskola. Eger.

2002-ben ismét gazdagodott a szakmai rendezvény, amely a tapasztalatok szerint nemcsak ismert, hanem elismert fórumává vált a magyar helyesírásnak. A bírálóbizottság jó része az akkori MTA Magyar Nyelvi Bizottság (ma: MTA Magyar Nyelvi Osztályközi

2 Időközben a kiadás feltételei megváltoztak, a tervezett két kötet (2015 és 2017) anyaga a jelen kötetben jelenik meg (a szerk.). 
Állandó Bizottság) tagjai közül került és kerül ki, az elnöki tisztet pedig általában e testület vezetője töltötte be. Időrendi sorrendben elnökölt Bencédy József, Fábián Pál, Pásztor Emil, Keszler Borbála, Balázs Géza és Prószéky Gábor.

A befektetett munka, az elért eredmények arra késztették a rendezőket, hogy gondoskodjanak azok méltó elismeréséről, akik sokat tettek a helyesírás oktatásáért és magáért a versenyért szervezőként, eredményes felkészítő tanárként, előadóként, zsűritagként. Így született meg a Nagy J. Béla-emlékplakett gondolata, amelynek megtervezésével és elkészítésével Király Róbert egri szobrászművészt bízta meg a főiskola. A dij odaítéléséről a volt és a jelenlegi tanszékvezetőkből álló kuratórium (V. Raisz Rózsa, Fekete Péter, Zimányi Árpád) döntött és dönt ezután is írásban rögzített elvek alapján. Az eddigi kitüntetettek:

Fábián Pál professor emeritus, 2002

Pásztor Emil főiskolai tanár, 2002

T. Urbán Ilona tudományos munkatárs, 2002

Bozsik Gabriella föiskolai tanár, 2003

Hangay Zoltán föiskolai tanár, 2005

Antalné Szabó Ágnes egyetemi docens, 2006

Fercsik Erzsébet föiskolai tanár, 2007

Laczkó Krisztina egyetemi docens, 2008

Keszler Borbála egyetemi tanár, 2010

A verseny népszerüségét többek között az is bizonyítja, hogy a 2000-es évek derekától kezdve egyre több határon túli, pedagógusképzéssel foglalkozó intézmény fogadja el az egriek meghívását, és küldi el legjobb versenyzőjét az immár kibővült Kárpátmedencei rendezvényre. A felkészítő tanárok többször előadást is vállalnak, sőt tanulmányokkal szerepelnek a konferenciakötetekben. Képviselteti magát a pozsonyi, a komáromi, a prágai, a kolozsvári, a nyitrai, az újvidéki, a kézdivásárhelyi és a beregszászi oktatási intézmény is. Ezért hoztunk létre egy olyan díjat, amelyet a legjobb eredményt elérő határon túli hallgatónak ítélünk oda.

A versenyzőknek a második napon, a versenyen két feladattal kell megbirkózniuk. Elsőként egy tollbamondást kell lejegyezniük, amely sokféle helyesírási nehézséget tartogat. Ezt követi az A és a B feladatlap megoldása, ahol a legkülönfélébb típusú gyakorlatokban kell dönteni például a magán- és a mássalhangzók időtartamáról, az igealakok írásáról, az összetételek, a különböző tulajdonnévfajták vagy a számok helyes jelöléséről, a sokféle írásjel alkalmazásáról stb. A versenydolgozatok jeligések, csak a bírálóbizottság eredményhirdetésekor válik ismertté a díjazottak neve. A feladatsor eddigi szerkesztői voltak: Szemere Gyula, T. Urbán Ilona, Kardos Tamás és Zimányi Árpád.

A verseny szabályzata elöírja, hogy a bírálóbizottságban tagként jelen legyen a tudományegyetemeknek, a tanítóképző és a tanárképző főiskoláknak, valamint a határon 
túli intézményeknek egy-egy képviselője, akik részt vesznek a dolgozatok elbírálásában. A versenyfeladatokat a Magyartanitás címü szakfolyóirat eddig rendre közölte, de magáról a rendezvényről, a díjazottakról az Édes Anyanyelvünk is beszámolt.

Végezetül egy táblázat bemutatja, hogy 1987-től kezdve a 25 versenyen kik azok a hallgatók, akik dicséretesen szerepeltek (1. táblázat). Az (m) jellel jelölt, illetve többszörös sorszámú hallgatók megosztva kapták a díjat.

1. táblázat

A Nagy J. Béla országos helyesírási verseny díjazottjai

\begin{tabular}{|c|c|c|c|}
\hline Év & Helyezés & Név & Az oktatási intézmény neve és helye \\
\hline 1987 & I. & Sarlós Valéria & Ho Si Minh Tanárképző Főiskola, Eger \\
\hline 1987 & II. & Ságiné Nagy Éva & ELTE Tanárképző Kar, Budapest \\
\hline 1987 & III. & Csetkovits Csilla & JATE BTK, Szeged \\
\hline 1988 & I. & Czuczor Erzsébet & Ho Si Minh Tanárképző Főiskola, Eger \\
\hline 1988 & II. & Vecsernyés Ildikó & JATE BTK, Szeged \\
\hline 1988 & III. & Nagy Judit & ELTE BTK, Budapest \\
\hline 1989 & I. & Márton Ágnes & Ho Si Minh Tanárképző Főiskola, Eger \\
\hline 1989 & II. & Nagy Szabolcs & $\begin{array}{l}\text { Comenius Tanítóképző Főiskola, } \\
\text { Sárospatak }\end{array}$ \\
\hline 1989 & III. & Antal Erzsébet & $\begin{array}{l}\text { Zsámbéki Tanítóképző Főiskola, } \\
\text { Zsámbék }\end{array}$ \\
\hline 1990 & I. & Denke Virág & KLTE BTK, Debrecen \\
\hline 1990 & II. & Papp Erika & $\begin{array}{l}\text { Békéscsabai Tanítóképző Főiskola, } \\
\text { Békéscsaba }\end{array}$ \\
\hline 1990 & III. & Molnár Barbara & JATE BTK, Szeged \\
\hline 1991 & I. & Ocskay Gyula & $\begin{array}{l}\text { Eszterházy Károly Tanárképző Főiskola, } \\
\text { Eger }\end{array}$ \\
\hline 1991 & II. & Dobsonyi Sándor & $\begin{array}{l}\text { Budapesti Tanítóképző Főiskola, } \\
\text { Budapest }\end{array}$ \\
\hline 1991 & III. & Rozmán Krisztina & $\begin{array}{l}\text { Zsámbéki Tanítóképző Főiskola, } \\
\text { Zsámbék }\end{array}$ \\
\hline 1992 & I. & Szabó Zita & $\begin{array}{l}\text { Békéscsabai Tanítóképző Főiskola, } \\
\text { Békéscsaba }\end{array}$ \\
\hline
\end{tabular}




\begin{tabular}{|c|c|c|c|}
\hline Év & Helyezés & Név & Az oktatási intézmény neve és helye \\
\hline 1992 & II. & Kollárik Péter & $\begin{array}{l}\text { Eszterházy Károly Tanárképző Főiskola, } \\
\text { Eger }\end{array}$ \\
\hline 1992 & III. & Némethné Új Éva & $\begin{array}{l}\text { Zsámbéki Tanítóképző Főiskola, } \\
\text { Zsámbék }\end{array}$ \\
\hline 1993 & I. & Kissimon Brigitta & ELTE BTK, Budapest \\
\hline 1993 & II. & Tóth Ildikó & $\begin{array}{l}\text { Körösi Csoma Sándor Főiskola, } \\
\text { Debrecen }\end{array}$ \\
\hline 1993 & III. & Boncsér Bernadett & KLTE BTK, Debrecen \\
\hline 1994 & I. & Öszi Gitta & JATE BTK, Szeged \\
\hline 1994 & II. & Szijártó Tímea & $\begin{array}{l}\text { Vitéz János Római Katolikus } \\
\text { Tanítóképző Főiskola, Esztergom }\end{array}$ \\
\hline 1994 & III. & Pethő Zsuzsa & $\begin{array}{l}\text { Budapesti Tanítóképző Főiskola, } \\
\text { Budapest }\end{array}$ \\
\hline 1995 & I. & Dudás Györgyi & KLTE BTK, Debrecen \\
\hline 1995 & II. & Barabás Edit & $\begin{array}{l}\text { Budapesti Tanítóképző Főiskola, } \\
\text { Budapest }\end{array}$ \\
\hline 1995 & III. & Szijártó Tímea & $\begin{array}{l}\text { Vitéz János Római Katolikus } \\
\text { Tanítóképző Főiskola, Esztergom }\end{array}$ \\
\hline 1996 & I. & $\begin{array}{l}\text { Beregszászi } \\
\text { Magdolna }\end{array}$ & ELTE BTK, Budapest \\
\hline 1996 & II. & Minier Márta & KLTE BTK, Debrecen \\
\hline 1996 & III. & Tarnai Beáta & ELTE Tanárképző Kar, Budapest \\
\hline 1997 & I. $(\mathrm{m})$ & Mártonfi Attila & ELTE BTK, Budapest \\
\hline 1997 & I. $(\mathrm{m})$ & Szabó Zsuzsanna & $\begin{array}{l}\text { Juhász Gyula Tanárképző Főiskola, } \\
\text { Szeged }\end{array}$ \\
\hline 1997 & II. & Fehér Brigitta & $\begin{array}{l}\text { Eszterházy Károly Tanárképző Főiskola, } \\
\text { Eger }\end{array}$ \\
\hline 1997 & III. & - & \\
\hline 1998 & I. & Dobány Margit & $\begin{array}{l}\text { Kölcsey Ferenc Református Tanítóképző } \\
\text { Főiskola, Debrecen }\end{array}$ \\
\hline 1998 & II. & Fábián György & $\begin{array}{l}\text { Bessenyei György Tanárképző Főiskola, } \\
\text { Nyíregyháza }\end{array}$ \\
\hline
\end{tabular}




\begin{tabular}{|c|c|c|c|}
\hline$\overline{E ́}$ & Helyezés & Név & Az oktatási intézmény neve és helye \\
\hline 1998 & III. & Cserháti Andrea & $\begin{array}{l}\text { Eszterházy Károly Tanárképző Főiskola, } \\
\text { Eger }\end{array}$ \\
\hline 1999 & I. & Bárdos Eszter & $\begin{array}{l}\text { Eszterházy Károly Tanárképző Főiskola, } \\
\text { Eger }\end{array}$ \\
\hline 1999 & II. & Gyarmati Ágnes & ELTE BTK, Budapest \\
\hline 1999 & III. & Deli Tünde & $\begin{array}{l}\text { Kölcsey Ferenc Református Tanítóképző } \\
\text { Főiskola, Debrecen }\end{array}$ \\
\hline 2000 & I-II. & Gáti Éva & $\begin{array}{l}\text { ELTE Tanító- és Óvóképző Kar, } \\
\text { Budapest }\end{array}$ \\
\hline 2000 & I-II. & Kocsis András & Debreceni Egyetem BTK, Debrecen \\
\hline 2000 & III-IV. & Vaszkun Anita & $\begin{array}{l}\text { Bessenyei György Tanárképző Főiskola, } \\
\text { Nyíregyháza }\end{array}$ \\
\hline 2000 & III-IV. & Fejes Edit & Szegedi Tudományegyetem BTK, Szeged \\
\hline 2001 & I. & Nagy Ilona & ELTE BTK, Budapest \\
\hline 2001 & II. & Zombory Katalin & $\begin{array}{l}\text { ELTE Tanító- és Óvóképző Kar, } \\
\text { Budapest }\end{array}$ \\
\hline 2001 & III. & Szegedi Éva & Szegedi Tudományegyetem BTK, Szeged \\
\hline 2002 & I. & Horváth Bernadett & ELTE BTK, Budapest \\
\hline 2002 & II. & Bírta Réka & $\begin{array}{l}\text { Eszterházy Károly Tanárképző Főiskola, } \\
\text { Eger }\end{array}$ \\
\hline 2002 & III. & Kékesi Csilla & Debreceni Egyetem BTK, Debrecen \\
\hline 2003 & I. & Veszelszki Ágnes & ELTE BTK, Budapest \\
\hline 2003 & II. & Selyem Zoltán & ELTE TTK, Budapest \\
\hline 2003 & III. & Szakál Marianna & $\begin{array}{l}\text { Eszterházy Károly Tanárképző Főiskola } \\
\text { BTFK, Eger }\end{array}$ \\
\hline 2005 & I. & Kozma Judit & ELTE BTK, Budapest \\
\hline 2005 & II. & Biró János & $\begin{array}{l}\text { Eszterházy Károly Tanárképző Főiskola, } \\
\text { Eger }\end{array}$ \\
\hline 2005 & III. & Huszár Ágnes & Veszprémi Egyetem TK, Veszprém \\
\hline 2006 & I. & Szegi Ádám & ELTE BTK, Budapest \\
\hline 2006 & II. & Bitai Tamás & $\begin{array}{l}\text { Szegedi Tudományegyetem TTK, } \\
\text { Szeged }\end{array}$ \\
\hline
\end{tabular}




\begin{tabular}{|c|c|c|c|}
\hline Év & Helyezés & Név & Az oktatási intézmény neve és helye \\
\hline 2006 & III. & Jakus Ágnes & $\begin{array}{l}\text { Eszterházy Károly Tanárképző Főiskola, } \\
\text { Eger }\end{array}$ \\
\hline 2007 & I. & Ludányi Zsófia & ELTE BTK, Budapest \\
\hline 2007 & II. & Juhász Péter & $\begin{array}{l}\text { Eszterházy Károly Tanárképző Főiskola } \\
\text { BTK, Eger }\end{array}$ \\
\hline 2007 & III. & Hasap Klára & $\begin{array}{l}\text { Pázmány Péter Katolikus Egyetem BTK, } \\
\text { Piliscsaba }\end{array}$ \\
\hline 2008 & I. & Sasvári Tünde Anita & ELTE BTK, Budapest \\
\hline 2008 & II. & Kovács Nóra & Szegedi Tudományegyetem BTK, Szeged \\
\hline 2008 & III. & Nagy Enikő & $\begin{array}{l}\text { Pázmány Péter Katolikus Egyetem BTK, } \\
\text { Piliscsaba }\end{array}$ \\
\hline 2009 & I. & Furuglyás Dóra & ELTE BTK, Budapest \\
\hline 2009 & II. & Dargai Bernadett & Eszterházy Károly Főiskola BTK, Eger \\
\hline 2009 & III. & Dsupin Éva & Miskolci Egyetem BTK, Miskolc \\
\hline 2010 & I. & Báthory Kinga & Eszterházy Károly Főiskola BTK, Eger \\
\hline 2010 & II. & Köllő Zsófia & $\begin{array}{l}\text { Babeș-Bolyai Tudományegyetem, } \\
\text { Kolozsvár }\end{array}$ \\
\hline 2010 & III. & Kovács Györgyi & ELTE BTK, Budapest \\
\hline 2013 & I. $(\mathrm{m})$ & Kocsis Teréz & ELTE BTK, Budapest \\
\hline 2013 & I. $(\mathrm{m})$ & Tóth Edina Bettina & ELTE TÓK, Budapest \\
\hline 2013 & II. $(\mathrm{m})$ & Kalla Viktória & Szegedi Tudományegyetem BTK, Szeged \\
\hline 2013 & II. $(\mathrm{m})$ & Lévai Zsuzsanna & Eszterházy Károly Főiskola BTK, Eger \\
\hline 2013 & III. & - & \\
\hline 2015 & I. & Szeverényi Melinda & Szegedi Tudományegyetem BTK, Szeged \\
\hline 2015 & I. & Tuska Borbála & ELTE BTK, Budapest \\
\hline 2015 & II. & Nagy Zsófia & Eszterházy Károly Főiskola BTK, Eger \\
\hline 2015 & III. & Farkas Linda & $\begin{array}{l}\text { a legjobb határon túli versenyző - } \\
\text { Comenius Egyetem, Pozsony }\end{array}$ \\
\hline
\end{tabular}


Az egri Líceumban harminc év alatt huszonöt verseny zajlott le eredményesen. Ez jogosítja fel a szervezőket, a helyesírást oktató kollégákat, a tudós szakembereket és nem utolsósorban a leendő versenyzőket a bizakodásra, miszerint a felgyorsult, modern technikai eszközökben bővelkedő világunkban is szüksége van mindannyiunknak az írásbeli igényességre és a kulturált helyesírásra.

\section{Irodalom}

Fábián Pál 1995. Nagy J. Béla (1884-1967) emlékének. In: Bozsik Gabriella - V. Raisz

Rózsa (szerk.): Helyesírásunk elvi és gyakorlati kérdéseiböl. Eszterházy Károly Tanárképző Főiskola. Eger. 9-13. 